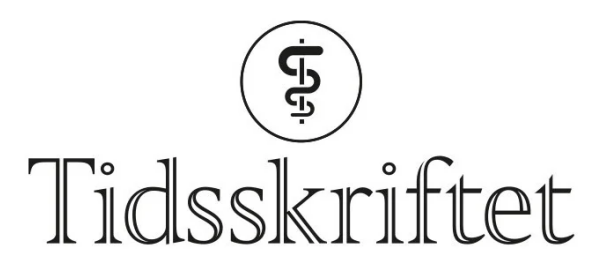

DEN NORSKE LEGEFORENING

\title{
Informativt og nyttig om hjerneslag
}

\author{
ANMELDELSER
}

HANNE ELLEKJAER

St. Olavs hospital

Avdeling for hjerneslag

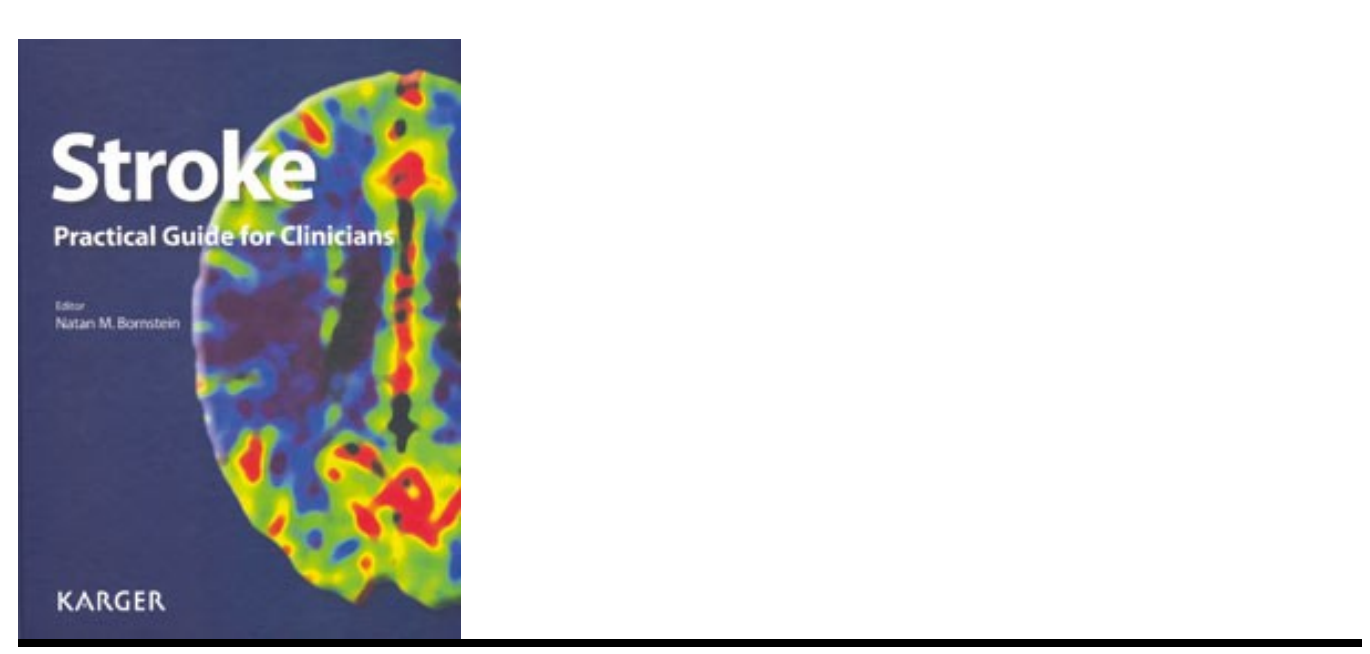

Bornstein, NM

Stroke

Practical guide for clinicians. 202 s, tab, ill. Basel: Karger, 2009. Pris CHF 198

ISBN 978-3-8055-9099-0

Bornstein og medforfattere har på litt over 200 sider gitt oss en oppdatert og velskrevet lærebok for klinikere som arbeider med hjerneslagpasienter. Hensikten er å gi leseren basiskunnskap om cerebrovaskulær patofysiologi, diagnostikk og behandling. Boken passer ypperlig for nykommere innen faget, men også som en oppfriskning av kunnskap hos den erfarne kliniker, da publikasjoner til og med 2008 er tatt med.

I atskilte kapitler gir anerkjente spesialister innen cerebrovaskulær medisin en grundig og oppdatert beskrivelse av sine «hjertebarn». Formen i de ulike kapitlene varierer og blir derfor mer eller mindre leservennlige. Men gjennomgående er fremstillingen lettlest, med fine illustrasjoner og tabeller. 
Medikamentelle tiltak er godt ivaretatt. Primærprofylakse og sekundærprofylakse er meget grundig og godt beskrevet med oppdatert litteratur. For norske lesere vil det sannsynligvis være mer naturlig å følge de norske retningslinjene som er under bearbeiding, enn de amerikanske som det i hovedsak refereres til.

Praktikeren og klinikeren vil nok savne en mer inngående beskrivelse av akutt behandling. Behandling av akutte komplikasjoner i akuttfasen og håndteringen av progredierende symptomer er ikke nevnt, heller ikke nevrokirurgiens plass i akuttbehandlingen. Prognostisering og vurdering av rehabiliteringspotensial er heller ikke nevnt og modeller for oppfølging og opptrening av slagpasienter etter utskrivning er også sparsomt beskrevet. Jeg savner også en beskrivelse av verktøy som benyttes for monitorering av pasienten i akuttfasen og kartlegging av funksjon.

Tyngdepunktet er med andre ord diagnostikk med en bred beskrivelse av nevroradiologi og ultralyd, som nok er begynnelsen på en ny æra hvor de kliniske konsekvensene så langt ikke er klarlagt. Det praktiske arbeidet med pasientene i en slagenhet er viet mindre plass.

Boken gir en god og interessant introduksjon til viktige ansvarsområder for en kliniker, men må suppleres med annen litteratur for å ivareta andre viktige aspekter av hjerneslagsykdommen, hvor det er viktig at legen også er på banen og engasjerer seg.

Publisert: 27. august 2009. Tidsskr Nor Legeforen. DOI:10.4045/tidsskr.09.0809

(C) Tidsskrift for Den norske legeforening 2023. Lastet ned fra tidsskriftet.no 26. april 2023. 